\title{
Visual Encounters in Global Shanghai. On the Desirability of Bodies in a Coworking Space
}

Aurélia M. Ishitsuka

\section{OpenEdition}

\section{Journals}

Electronic version

URL: https://journals.openedition.org/chinaperspectives/10416

DOI: 10.4000/chinaperspectives. 10416

ISSN: 1996-4617

\section{Publisher}

Centre d'étude français sur la Chine contemporaine

Printed version

Date of publication: 1 September 2020

Number of pages: $39-46$

ISSN: 2070-3449

\section{Electronic reference}

Aurélia M. Ishitsuka, "Visual Encounters in Global Shanghai. On the Desirability of Bodies in a Coworking Space", China Perspectives [Online], 2020-3 | 2020, Online since 01 September 2021, connection on 10 December 2021. URL: http://journals.openedition.org/chinaperspectives/10416 ; DOI: https://doi.org/10.4000/chinaperspectives.10416 


\title{
Visual Encounters in Global
}

Shanghai: On the Desirability of Bodies in a Coworking Space

\author{
AURÉLIA M. ISHITSUKA
}

\begin{abstract}
The rise of Shanghai as a global city prompts the question: to whom does it belong? This article addresses the issue by examining the desirability of bodies in one of the city's cosmopolitan spaces: a coworking space patronised by an international clientele. Drawing on an analysis of visual encounters in both physical and virtual spaces, it shows that the logic of belonging in the coworking community is based on the distinction between two kinds of bodies: the desirable one of the transnational professional and the undesirable one of the rural-urban migrant worker. While the latter is reduced to its working function, the former appears as a body complete with desires, whose interactions with others blur the separation of the professional and the intimate in line with the new spirit of capitalism. This visual ethnography provides insights on how economic changes reshape Shanghai's urban life not only by reproducing local patterns of social exclusion, but also by encouraging racialised desires suited to capitalist accumulation on a global scale.
\end{abstract}

KEYWORDS: Coworking space, community, bodies, visual encounters, new spirit of capitalism, global city, Shanghai.

\section{Introduction}

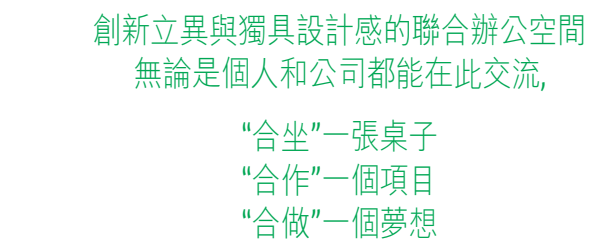

Our innovative and beautiful workspaces are home to a diverse community of companies and individuals who

\section{INTERACT \\ COLLABORATE \\ AND DO BUSINESS WITH ONE ANOTHER}

Founded by a white South African entrepreneur with his Hong Kongese architect wife, the Hub is a coworking space provider that has been operating in Shanghai since late 2015. ${ }^{1}$ In April 2018, at the time of its acquisition by an American giant among the shared office providers, it already had 24 locations across Asia - 15 in Shanghai alone, with the others in Beijing, Hong Kong, and Vietnam - and more than 10,000 members. ${ }^{2}$ As indicated by the promotional material quoted above, the Hub's marketing strategy is to emphasise the collaborative dimension of the coworking experience: it attracts free-lancers, start-ups, small and medium-sized enterprises, and branches of multinational corporations not only by promising reduced costs, office service, flexibility, and a "fun" working environment, but also, and more importantly, by promoting itself as a platform that facilitates social interactions. ${ }^{3}$ In other words, it claims to be, besides an office space, a cross-border community.
While the Hub's sales pitch of being more than a place where people "work alone, together" (Spinuzzi 2012) should not be taken at face value, it has, at least for some of its patrons, become tangible: the Hub occupies a central position in the everyday lives of foreign and Chinese young mobile professionals in Shanghai. As such, it can be counted among the emerging globalised local communities that have appeared with the rise of Shanghai as a global city (Chen 2009), a process that has prompted the question of to whom the city really belongs (Sassen 2009: 20). The issue of urban belonging is addressed here by way of an examination of the socio-spatial logics of inclusion and exclusion in the Hub. This approach follows recent warnings by scholars of globalisation against understating the relevance of emplacement and embodiment in the study of transnational subjects (Conradson and Latham 2005; Dunn 2010; Niekrenz, Witte, and Albrecht 2016). Hence, my study takes the body as its primary scale of analysis, leading to the following reformulation of the question of belonging: what kinds of bodies and arrangements of bodies are desirable in the Hub?

Bodies appear in this study as they become legible through visual encounters. Here, I conceive of visual encounters in three ways. First, this

1. For reasons of anonymity, I use a pseudonym in place of the company name.

2. This paper focuses on the Hub prior to the changes in interior design and organisation that started to be implemented in January 2019.

3. While both texts insist on the collaborative dimension of the coworking space, the English version differs from the Chinese one, which in a more literal translation reads: "In [our] innovative and uniquely designed coworking spaces, anyone, whether a person or a company, can interact, share a table, share a project, share a dream." (Chuangxin liyi yu duju shejigan de lianhe bangongkongjian wulun shi geren he gongsi dou neng zai ci jiaoliu, hezuo yi zhang zhuozi, hezuo yi ge xiangmu, hezuo yi ge mengxiang). 
notion refers to what Sara Ahmed calls the visual economy of recognition, which is the process by which, during social contacts, individuals see the difference between familiar and strange others. In this perspective, encounters are face-to-face interactions that reopen past encounters; as individuals read others' bodies along gender, racial, and class histories, they recognise those who belong and those who are out of place (Ahmed 2001). I frame this distinction in terms of desirable and undesirable bodies, a terminology that conveys the importance of self-image and appearance in a coworking environment imbued with the new spirit of capitalism (Boltanski and Chiapello [1999] 2011). Second, I also treat visual encounters in the sense of depicted encounters, since the object of analysis is not only social interactions in the physical space, but also their representation in the various media used in the Hub: a mobile app, silent video displays, and promotional posters. Finally, this expression reflects the attention accorded by the study to how bodies gaze and are exposed to view in the coworking space.

As a methodological choice, the visual approach assumes that the analysis cannot be disentangled from the position of the ethnographer on site. The standpoint of this study is that of an Asian-French female researcher in her late twenties who spent several days a week in the Hub for a total of ten months, spread out over a period of two years (2017-2019). I was first introduced to the coworking space by a Chinese male friend working in a European start-up based at the Hub's location in the commercial area of Xintiandi. In the spring of 2017, my friend would regularly let me into the space, where I would work alongside him and his colleagues. Upon returning to Shanghai the following year, I subscribed as a member to get access to multiple Hub locations before switching, for the final phase of my fieldwork, to a pay-per-hour plan. Early on I built close connections with the team around my initial informant and then expanded the investigation by participating in events and interacting with young professionals in the Hub, with whom I conducted interviews on an ongoing basis. Although I presented myself as an academic researcher of young professionals, activities such as writing my fieldnotes on a laptop, taking part in video conferences with colleagues abroad, and joining lunches and events made me indistinguishable from other members of the community.

Through a visual ethnography of bodily encounters, I first explore the dilemma faced by a company that promises its members the experience of a class-exclusive community while depending on unskilled labour to maintain its facilities. I then turn to the ways in which the coworking space encourages, for its patrons, a blurring of the lines between work and play, professional and intimate. On the basis of this analysis of spatial organisation and social norms of interaction, I propose that what is at stake in the visual management of bodies is not only the reproduction of social differentiation but also the management of desire.

\section{In and out of sight: The visual paradox of undesirable bodies}

\section{Keeping them out: The community watch and the stranger}

In 2005, Brad Neuberg, an employee of a start-up in San Francisco who has been credited with coming up with the idea of the coworking space, was unhappy with the lack of social ties between patrons of the rent-anoffice space where he was working: "I couldn't figure out how to have freedom and community at the same time. ${ }^{14} \mathrm{He}$ was confronting an issue that "gives philosophers a headache with no known cure" (Bauman 2001: 20), and if his solution to reconciling the two needs had no immediate impact in the field of philosophy, it did become a successful business model across the world. Before long it had spread from the West Coast of the United States to China's east coast (Wang and Loo 2017). While some local brands in Shanghai focus solely on coworking as a resource sharing space (Wu 2018), the Hub is loyal to Neuberg's initial aspiration: it presents itself as a "community" (社區 shequ) of "members" (會員 huiyuan), terms that emphasise the collective dimension and obscure the commercial contract on which the relationship between the Hub and its clients is based.

This vocabulary echoes a physical structure that is carefully designed to provide a sense of community. Most of the surface is taken up by a common area, and larger firms that require separation are placed in seethrough offices enclosed by glass walls that do not break the impression of an entirely open space. The connecting node of the common area is a large space with tables, sofas, chairs, and a bar that offers complimentary coffee, tea, soda, and beer (see Figure 1). In the Hub's terminology, this is called the "living room" (客廳 keting), an analogy with the residential home that matches the ambition to abolish the borders between work and private life. The coworking space thus perfects a strategy that employers have long pursued: to provide a homelike working environment that would reduce stress and increase productivity (Hochschild [1997] 2001). To foster everyday interactions, the Hub encourages its members not only to work, in the strict sense of the term, but also to eat, drink, and socialise, notably by engaging in daily events organised by the "community team" (社區團隊 shequ tuandui). This refers to the portion of the staff responsible for managing memberships, and whose main role is, to borrow the Hub's own expression, "to bring people together."

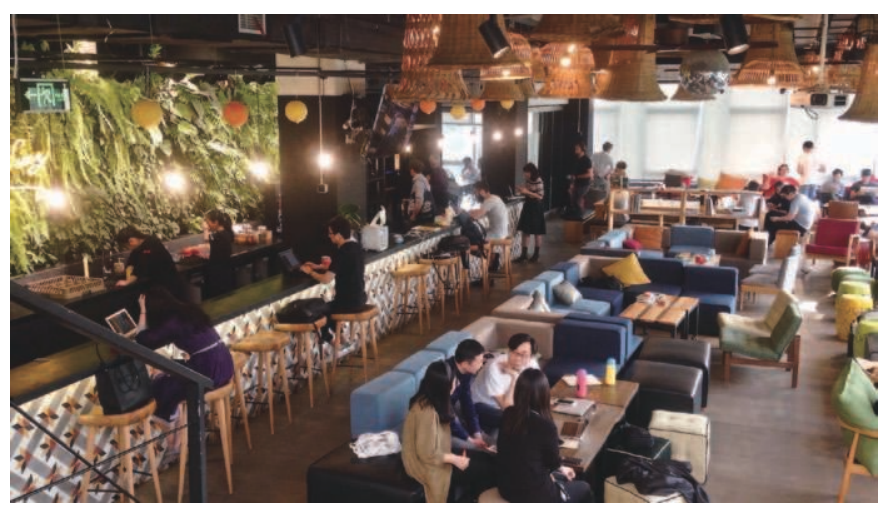

Figure 1. The Hub's living room. Members are working on their laptops, holding meetings, and conversing by the coffee maker. By the sink behind the counter, a cleaning lady can be seen washing cups. Credit: photo courtesy of the author.

Access to the Hub, a for-profit company first and foremost, is subject to payment. Doors with electronic locks delimit the physical boundaries of the space: from the outside, clients have to swipe their member cards or use the app on their phone to unlock them, while from the inside, pushing a button suffices. For those who do not wish to sign a monthly membership contract (starting at 1,800 RMB), the Hub eventually introduced an option to "pay-asyou-go" (15 RMB/hour), which enables anyone to scan on arrival a barcode that will unlock the door, allowing admittance to the space under a minutebased payment scheme. This access method, which gives members the

\footnotetext{
4. Joel Dullroy, "Coworking Began at Regus... but Not the Way They Think," Deskmag, 4 April 2012, http://www.deskmag.com/en/coworking-did-begin-at-regus-but-not-the-way-they-think-362 (accessed on 28 July 2019).
} 
freedom of joining and leaving as they please, reveals that the Hub exhibits core elements of an aesthetic community whose social bonds, "like the attractions on offer in theme parks (...) are to be experienced on the spot," rather than those of a community built around "ethical responsibilities" and "long-term commitments" (Bauman 2001: 71-2). In this regard, one can say that the Hub sells the experience of a community. Ideally, this experience should be available anywhere, which drives the multiplication of the Hub locations around the world. It shouldn't be, however, within anyone's reach: the price of entry works as a selective mechanism that prevents poor bodies from coming in. In this way, the Hub is a class-exclusive space that resembles Shanghai's most expensive leisure venues (Farrer 2009).

The Hub's concern with controlling the bodies entering and exiting the space derives from the need to make members pay for using the facilities as much as from the necessity to maintain its image as a high-end working environment. In practice, however, control is rendered difficult due to the contradiction in the branding of the Hub as a global nexus that connects flows of information, money, and bodies. The doors to the space are constantly being opened during regular office hours by members who leave the premises temporarily to smoke, shop in the next-door mall, eat outside, or meet clients. Moreover, one of the Hub's selling points is that it functions as a platform for business transactions, which makes it imperative that the coworking space is not strictly limited to its members. Therefore, the Hub not only hosts external events, but also allows members to bring in "visitors" (訪客 fangke). While registering visitors at the front desk is mandatory in theory, it is seldom implemented in practice. As most facilities cover several floors, each of which is directly accessible via an elevator, members and their visitors don't feel compelled to stop by the reception desk at the main entrance.

On occasion, the need to regulate access noticeably affects the Hub's image as a welcoming and friendly space. This happened one day in November 2018, when members at the Xintiandi location found a notice posted by the entrance doors reminding them to swipe their membership cards to enter, as opposed to the common practice of holding the doors open to let each other in. Most importantly, it asked them to report strangers to the community team (see Figure 2). The image of a surveillance camera, which corresponds to the numerous actual cameras installed in the space, underlines that the intention is to keep the community "safe" (安全 anquan). This rhetoric of safety recalls the imperative of watching out for possible intruders that is at the heart of neighbourhood watch schemes in American and British middle-class residential areas (Ahmed 2000). Like the good neighbour, a Hub member is expected to protect the community from the threat of "suspicious" (可疑 keyi) persons attempting to enter the space. Members are supposed to recognise the strangers even without any description provided. The only piece of information given is that the stranger is someone who is "trying to enter [sic]" (尾隨 weisui, lit. follow) while not belonging to the category of "us" (我們自己women ziji). Following Sara Ahmed (ibid.), we can understand the absence of information not as an accidental omission of the markers that identify the stranger, but rather as an indication that the knowledge on which the identification is based is commonsensical. In other words, it becomes superfluous to explicitly state how the stranger looks or acts, since a shared knowledge of the stranger's appearance is assumed.

In Shanghai, the bodies that are already recognised as strange others are those of the Chinese rural-urban migrants. As in other major Chinese cities, the low-paid labour force is created by internal migration from rural areas in the less developed interior (Roulleau-Berger and Shi 2005). These migrant

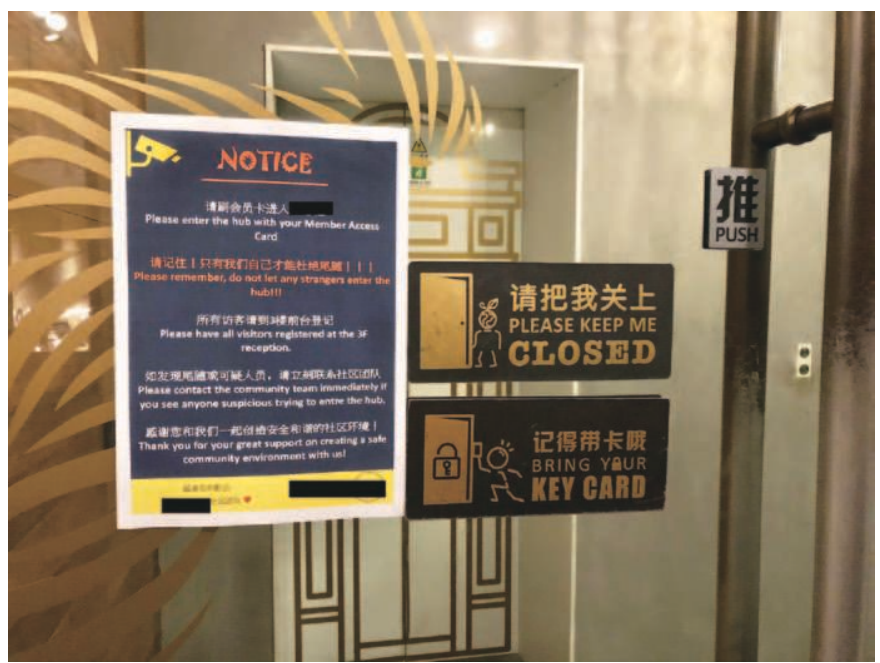

Figure 2. A bilingual notice pasted on one of the entrance doors of the Xintiandi location. In the background, one sees one of the two elevators allowing direct access to other floors. Credit: photo courtesy of the author.

workers are considered undesirable urban subjects, much like the immigrant workers who undertake a large part of low-skilled work in global cities in the rest of the world. The migrant workers often live under precarious conditions and constitute a stigmatised population associated with social disorder and crime (Zhang 2001). The potential peril that they represent is associated in the public imagination with an "unattractive physical appearance" characterised, for example, by "unfashionable, dirty and work-worn clothes" (Guan and Liu 2014). Considered a disturbing presence in the cityscape, these migrants are subject to close watch: they are targeted by police controls in the street (Han 2010) and chased from gated residential compounds (Pow 2007). And yet, global cities cannot do without these bodies as they perform the physical and affective labour that renders the lifestyle of the upper and middle-classes possible (Zhang 2010). When the Hub enlists its members to watch out for strangers, it faces the same dilemma. It strives to keep out undesirable rural-urban migrant bodies but delegates to them the "dirty work" (Hughes [1951] 1994) required to maintain the coworking space. The tension is resolved through the conditioning of their access.

\section{Letting them in: Marking and masking rural-urban migrant bodies}

To fulfil the managerial dream of complete flexibility, the Hub is open 24 hours, seven days a week. Unlike some services, such as membership renewal, that are not available at all times, the task of watching out for intruders must be performed constantly. When the community staff are not present - at night-time and during public holidays - this task is carried out by security guards. The irony is that the security guard is himself a migrant worker (Pow 2007). Therefore, the Hub needs to distinguish unuseful and therefore suspicious bodies from those performing a necessary function. Clothing is central to this operation, as the wearing of uniforms is what identifies a specific subset of rural-urban migrant bodies as the ones who should be let in. These work outfits function as a laissez-passer. They render evident the purpose for entering and thus enable stigmatised bodies to be physically included in the coworking space, where they perform the constant maintenance required to keep the Hub running.

Security guards are not the only migrant workers tolerated in the proximity of the Hub. As only snacks can be purchased in the Hub, ordering food to eat with colleagues in the living room is an affordable and timeefficient alternative for members who do not bring home-cooked dishes 
and do not wish to eat at a restaurant. If digitalisation has dispensed the flow of information of its immediate materiality, the delivery of food and packages still requires working bodies. In this sense, the deliverymen give physical presence to the otherwise invisible human infrastructure on which China's digital economy rests (Yu 2017). Throughout the day, and especially during lunchtime, a constant stream of bodies in bright-colour uniforms and motorbike helmets passes up and down the stairs and elevators that lead to the Hub's various floors. Although the deliverymen are allowed to approach the coworking space, they are never actually let inside. Those carrying packages are forbidden to pass the reception desk, where they are expected to hand over their parcels to the community team. As for the food couriers, they cannot even cross the threshold but have to leave the meals on the shelf of an in-between space delimited either by two glass doors or, on the upper floors, the elevators and a glass door (see Figure 2). As part of what maintains the hygiene of the community (Ahmed 2000: 25), this area resembles an air lock that keeps the community pure from pollution in the form of rural-urban migrant bodies.

Some tasks, however, cannot be performed without physically letting the strange bodies inside the space. Cleaning cups, putting them in the dishwasher, wiping tables, adding water to teapots, resupplying the coffee machine with coffee beans and milk, caring for plants, putting chairs back in place at the end of the day, cleaning toilets, taking out garbage - these are all responsibilities of the cleaning ladies. Male janitorial staff only come in sporadically to repair plumbing or failing electrics. On the one hand, the presence of middle-aged female workers is less disruptive than that of the myriad deliverymen, as there are far fewer of them (each one is assigned her own floor). On the other, they are a constant presence within the coworking space between 7 am and 7 pm, Monday to Friday. The cleaning ladies are thus let into the space while the deliverymen are kept out, a difference in access that translates into a difference in the uniforms worn. The outfits of the cleaning ladies consist of dark trousers and a black sweater with the Hub's white logo that stand in sharp contrast to the colourful uniforms of the deliverymen. While the latter's uniforms serve a safety function by making them visible in traffic, the uniforms worn by the cleaning ladies have an aesthetic purpose instead. The choice of dark uniforms makes them unobtrusive but nevertheless distinguishable inside the otherwise colourful living room of the Hub, effectively rendering them invisible until such time that they are deemed useful (Hanser 2008: 107). The dark clothing thus fulfils the dual requirement of marking the undesirable bodies while rendering them discreet.

The need to offset the disturbing presence of these bodies appears clearly through the visual narratives conveyed by promotional posters and videos, which are prominently displayed in the living room, albeit muted so as to avoid any disturbing noise. Unlike the members and the community team, the cleaning ladies are not represented in these media, and neither, it goes without saying, are the security guards or deliverymen. Although the visual absence is somehow coherent with the Hub's hiring practices, which rely on the outsourcing of cleaning and security staff, it is nevertheless striking, because some of the services provided by the cleaning ladies do appear on screen. For example, one short video features a man who is sitting in a shiny clean toilet looking for paper. Cut to a shot outside, where a young Asian man with big white wings on his back is running through the tree-lined streets of the former French Concession, wearing sneakers and the Hub's sweater. The final scene returns to the toilet to show the be-winged man throwing toilet paper to the first man through a small window, saving him from potential discomfort in a timely manner. This video is one in a series promoting Hub Angels, the name given to the otherwise faceless staff that members can contact on the Hub's mobile application for assistance. The choice of representing the task as if done through magic reflects the will to conceal the actual work needed to maintain the space. Furthermore, the substitution of the middle-aged migrant female body performing its task for divine intervention by a young male body illustrates the inconceivability of representing dirty bodies on screen, as it would disrupt the idea of a homogeneous and pure community. In this regard, the Hub's visual management of dirty bodies illustrates how those who "cannot be physically removed" are "eliminated culturally" (Bauman 2001: 57) and, in particular, how the non-recognition goes to the point of erasing the labour they perform.

Undesirable bodies have to be kept in sight and under surveillance so as to control their access to the Hub, as well as out of sight, noticeable only when necessary. However, as shown by the case of the security guard, these bodies are also looking subjects. The cleaning ladies are supposed to keep an eye on the space: they need to spot dirt so they can make it disappear. As looking also means working, they sometimes deliberately look away. In the open space of the Hub, looking away becomes especially important as a technique to avoid work, because there is no "backstage" (Goffman 1956) save for a changing room the size of a closet. In this setting, both hiding in plain sight (for example by standing behind a pillar or sitting in a chair facing the wall) and avoiding eye contact (by looking down at their smartphone) are acts that seek to avoid being seen as a subject who can see. Since being seen means being identified as a working body, invisibility is not only imposed on the cleaning ladies but can also be a way to resist the labour regime, all the more since being noticed as a service worker can lead to having to execute tasks outside of one's regular duties, as on one afternoon in November 2018 when a startup celebrating an employee's birthday asked "the ayi" to take a group picture. ${ }^{5}$ As eleven people, including the ethnographer, posed and smiled, she struggled to press the right smartphone button. When she finally managed to take a picture, she performed the work of fixing desirable bodies on screen.

\section{Desirable bodies on display: From self-branding to perfect matching}

\section{Managing successful bodies, exposing attractive selves}

First and foremost, the Hub's desirable bodies are those of the clientele: mobile professionals who come mostly from China or various countries in Europe, North America, and Asia. The majority are entrepreneurs, project managers in small foreign companies, start-uppers, and freelancers in their late twenties and thirties, with the exception of a few middle-aged whitecollar workers who are mostly seen going in and out of their private offices. In addition to the clients, the community team can also be counted among the desirable bodies. These employees are all Chinese and mostly, if not exclusively, female, reflecting the conventional gendering of hosting work. Like many Chinese Hub members, they are recent university graduates who

\footnotetext{
5. Unlike the members of the community team who are called by their English names, the cleaning staff are never addressed by name but instead by the word ayi 阿姨 (literary "aunt"), a familiar form of address broadly used for middle-aged women.
} 
have studied abroad, often in Australia, Europe, or North America. Unlike the cheap labour of migrant workers, they are directly employed by the Hub rather than through a subcontractor. Team members, then, not only support the community but are part of it. Their inclusion in the community is mirrored by their representation in the videos displayed in the living room and by the freedom they have to wear their own clothes, which makes them visually indistinguishable from the clientele as soon as they leave the reception desks.

Clients and community staff employees dress in a manner reflecting their membership in a globally mobile middle class. They wear clothes and accessories purchased abroad, whether on a business trip to Hong Kong, a visit to friends and relatives in Europe, or on vacation in Japan. While the homogeneity of style can in part be explained by the class-selective admission to the space, the location of the premises, in gentrified areas with high-end shopping malls and boutiques for international luxury brands, creates further incentive to look fashionable. When, twice a year, the living room of the Xintiandi location is used to store clothing for the Shanghai Fashion Show that takes place in a nearby park, employees and clients who do not pay attention to their appearance might quickly feel out of place. The style of clothes favoured by Hub members is in line with a global startup culture originating from Silicon Valley that privileges more or less casual outfits over business formal attire (Casanova 2015: 14). Although these young professionals might dress up in suits, with polished leather shoes and high heels, to attend formal meetings or events, they otherwise prefer urban cool leisure wear and sneakers.

The relaxed way of dressing conveys not only global mobility but also sportive activity. As they arrive in the morning or return after the lunch break, Hub members will notice the sports bags carried by their peers, which signal that they are coming directly from a session at a nearby gym. The Hub actively promotes this lifestyle by showing videos of members working out in the living room. Each location offers some opportunities for exercise - such as stationary bicycles, table tennis equipment, and weekly yoga classes and showers free of charge. With the physical training comes a heightened awareness of diet. When the deliverymen come with lunch orders, the number of expensive Western-style salads and Japanese set meal reveals the dietary preferences of the members. The habit of my main informant, who would invariably ask via his app that the kitchen use less oil when preparing his order of Chinese food, is characteristic of a prevalent attitude toward healthy eating. Despite taps for beer and soda being prominently placed in the living room, Hub members use them in moderation, as many are concerned with limiting their sugar intake. By contrast, coffee cups quickly accumulate in the sink. This observation illustrates how the concern with a healthy lifestyle becomes entangled with considerations related to work performance. The members' taste for coffee responds to the need to focus for long hours and therefore, like a stress-releasing yoga session, promises to increase productivity.

Through this shared lifestyle, members work on themselves to come closer to the ideal managerial body: one that is active and flexible (Longhurst 2001). These bodily attributes correspond to the overall values of the new spirit of capitalism, which celebrates individuals who are mobile, connected, and adaptable (Boltanski and Chiapello [1999] 2011). Just as older Chinese businessmen's bodily bulk, cultivated over years of business dinners featuring heavy drinking, symbolises power and wealth (Hird 2009: 131; see also Osburg 2013), young professionals' fit bodies are a sign of success and selfcontrol. For the purposes of self-branding, the display of an attractive body is no more important than making known the intense bodily management through which it was allegedly produced. Unlike many other forms of bodily labour, most notably the affective labour of women, the process of attaining the perfect body is not erased here but recognised as "work that adds value" (Otis 2011: 17). Moreover, while this lifestyle may be enjoyable, the value is inextricably linked to it being collectively perceived as strenuous. For example, young professionals in the Hub make a point of mentioning the discipline needed to wake up early and make it to a gym session before work. What may at first seem contradictory to the "fun" working atmosphere of the Hub is in fact the meritocratic justification of their status: sacrifices have to be made and returns postponed to climb the ladder of success.

The members therefore see their bodies as investments, and so does the Hub. For the company, desirable bodies become profitable through "ambient marketing" (Hearn 2008: 210). In one promotional video that shows interviews with members, a 50-year-old white male shares his excitement at working in an environment where he is "surrounded by hip urban excited millennials." As youth signifies innovation, the presence of young bodies on screen and in the physical space is used in the marketing of the space to attract larger companies. In the same way as age plays into the miseen-scène of bodies in the Hub, so does race. During a tour in April 2018, led by the community staff to showcase the space to potential clients, a group of middle-aged Chinese businessmen deliberately framed the pictures they were taking so as to include white young professionals. Due to the "international flavour" that comes with foreign presence (De Giorgi 2017: 115), whiteness becomes a commodity that the Hub uses to attract Chinese clients, not unlike in Shanghai's clubbing scene.

The logic of displaying bodies in the Hub shares several commonalities with cosmopolitan nightlife venues in the city. An ethnographic study of disco clubs in the 1990s argues that young Chinese find an exhibitionist pleasure in being observed in an international setting; this gives them a sense of being modern consumers and desirable commodities belonging to a cosmopolitan world (Farrer 1999). Likewise, in the Hub, being seen in the company of transnational businessmen, Chinese and foreign, makes urban Chinese professionals feel they are part of a global community. The same is true for non-Chinese clients, especially those who come from smaller cities in their home countries, for whom exposing themselves in a coworking space in one of the foremost metropoles in the world becomes a way to gain status. In the visual consumption of bodies, only the gaze of the desirable others is consequential: recognition by those whom the members themselves consider desirable is what to produce a sense of communal belonging.

To be subjected to the gaze of one's peers entails being exposed to the judgement of others. In early January 2019, a Chinese woman working out of the Xintiandi location posted on the common wall of the Hub's mobile application a picture of a toilet seat covered by a layer of toilet paper. She commented on the picture by expressing her dissatisfaction with this kind of behaviour, stressing the lack of manners reflected by this act. For her, the toilet paper was evidence of someone squatting over the toilet bowl as if using a latrine of the type most common in China. In her comment, she also explained her disappointment as related to the expectation that other members of the coworking space would have the education necessary to properly use a sitting-style toilet. Apart from showing how mutual observations among members can easily become a tool of surveillance that disciplines behaviours, the anecdote illustrates that a similar habitus and shared values are what members are looking for upon joining the Hub. Since a coworking space is where one hopes to gain professional recognition and expand one's network (Gandini 2015), the member's dismay can be read as 
a reaction to a perceived failure on the part of the Hub to filter out persons who do not fit the criteria of a potential partner.

\section{Meeting each other's eyes: Looking for the ideal partner}

Hub members who frequent the same facilities will familiarise themselves with each other and build social ties, but do not have the same opportunity to connect with members who are based in other locations in Shanghai or even in other cities in Asia. To encourage social bonds despite the lack of physical proximity, the Hub has launched a mobile application. Its users - that is, members and community team employees - can build up their profiles by uploading pictures, filling out job positions, and entering hobbies. The application encourages the inclusion of information on leisure activities and personal preference, not because the Hub is a place for informal interactions but rather because such data play a part in the choreography of enterprising interaction (de Peuter, Cohen, and Saraco 2017). The spirit of capitalism that infuses the Hub does not differentiate between work and play, as members need always to appear active, always engaged in a new project, and through this constant drive they are brought together with likeminded individuals (Chiapello and Fairclough 2002: 192). On the common wall, posts promoting users' businesses mix with personal announcements, forms of expression that contribute equally to the image of desirable bodies as bodies with desires.

The conflation of professional and personal desires that characterises the project of neoliberalism (Lordon 2014) is perfectly captured by the networking feature of the Hub application, which is modelled on a popular dating application. The user can choose to follow other members by a swiping motion, and thereafter keep track of members they follow and who follow them, as well as review a list of mutual followings (see Figure 3). By selecting an attractive profile picture, the user can present him or herself as the ideal professional and sexual partner. In the Hub, the desirable bodies are the sexualised ones, in contrast to the otherwise frequent representation of undesirable foreign migrants, whose sexualised bodies appear as a problem or even a threat in nationalist discourse (Goh 2014). Here, sex is not associated with promiscuity or rampant hypersexuality but with glamour. Through the application, the Hub provides a space for legitimate sexual desire - one of the drives bringing members together.

In its marketing, the Hub openly promotes a narrative of the coworking space as a site for both professional and sexual encounters. For example, a flyer advertising a bachata class scheduled for March 2018 depicts a man in a suit and a long-haired woman in a red dress closely intertwined; the caption makes explicit that the class is an occasion to "meet romance and opportunity." To give another example, a promotional video playing on a loop in the Nanjing Road location features a male Chinese start-upper looking into the camera, testifying that the Hub is a great place for "meeting potential employees." The video continues with a shot of a young man: "It's easy to get dates [in the Hub]. 'Do you wanna check this out?' Boom! It's the perfect set up." Both the poster and the video draw on old tropes of heterosexual romance. One showing a man leading a woman in a popular social dance, the other glorifying a man tricking a woman into his arms.

While the dating narrative is predominantly heteronormative, some visual media suggest same-sex encounters. A poster promoting the Hub's networking application shows "Francisco" and "Jin" meeting at the counter (see Figure 3). On the left, we can see the application's interface, indicating that this was how the two met. This encounter between two men can be read in two ways. First, it can be interpreted as a homosocial encounter conveying the idea that business happens when men meet other men. Even

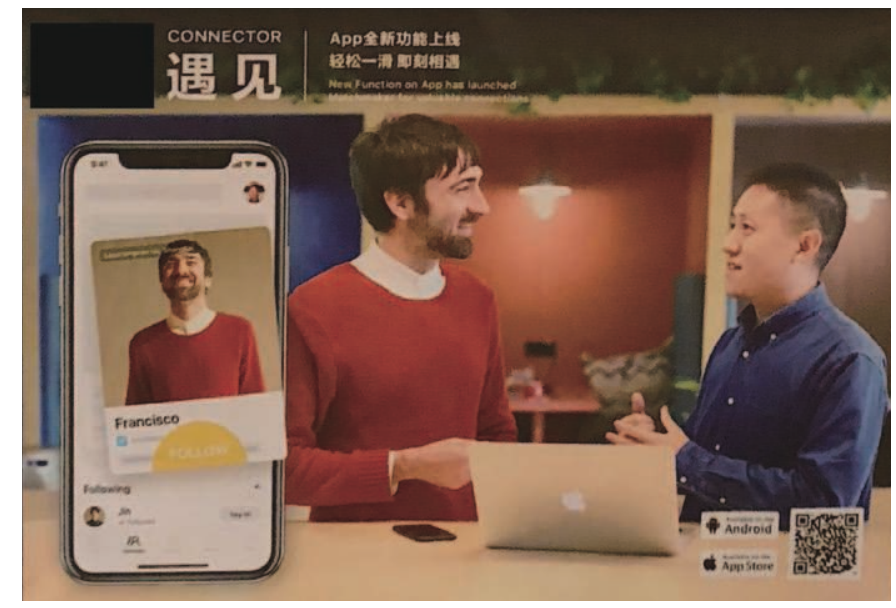

Figure 3. Picture of a poster advertising the Hub application's matchmaking function. Credit: photo courtesy of the author.

though female bodies are as present as male ones in the coworking space, professional encounters between women are lacking in the promotional material. A second way to understand the poster is that it depicts a romantic encounter between two men since, as shown above, the Hub's application is designed for both dating and business. The ambiguity of the poster testifies to the increasing visibility of male gay identities in the transnational business environment (Connell and Wood 2005). Although the space remains heteronormative, the Hub makes no effort to conceal male homosexual encounters, since these help its brand as a company that meets liberal expectations for tolerance and diversity.

The meeting between the two men is also symptomatic of the Hub's celebration of interracial encounters. One of the most emblematic examples is a promotional video starting with the question: "Why can't love happen in the most unlikely place?" It depicts a meeting of an Asian woman and a white man in their early thirties. In the common restroom, we see the woman, wearing a scarf over a lavender jacket, looking at herself in the mirror as she applies scarlet lipstick. Next to her is a bespectacled man in a beige blazer also looking in the mirror to groom his hair. When the woman accidentally smears lipstick on her cheek, the man assists by handing her a tissue. Following a close-up of her smiling at him, the video ends with the two walking out together. On the wall of the corridor are the words: "If you never try, you'll never know" (see Figure 4). This story clearly draws upon a legend in the world of start-ups: the meeting between Facebook CEO Mark Zuckerberg and his wife and business partner Priscilla Chan. Today, it is popular knowledge that the couple met while queuing up for the bathroom at a Harvard fraternity party. ${ }^{6}$ This success story, which echoes the one of the Hub's founding couple as well the many other "joint-venture marriages" in Shanghai (Farrer 2008), encapsulates the configuration white male - Asian female as an ideal romantic and business partnership.

The reproduction of this same configuration in the physical space betrays the racial and gender division of labour of a workplace catering to foreign start-ups. In the Hub, I saw many variations of the scene in which the man engages the woman through the simple gesture of handing her a tissue, as Western male entrepreneurs sought out Chinese women to collaborate on their projects. With globalisation, educated women appear as perfect

6. Madeline Stone and Paige Leskin, "The 16-Year Relationship of College Sweethearts Facebook CEO Mark Zuckerberg and Priscilla Chan," Business Insider Australia, $1^{\text {st }}$ August 2015, https:// www.businessinsider.com.au/mark-zuckerberg-and-priscilla-chans-12-year-relationship-inphotos-2015-7 (accessed on 14 December 2019). 


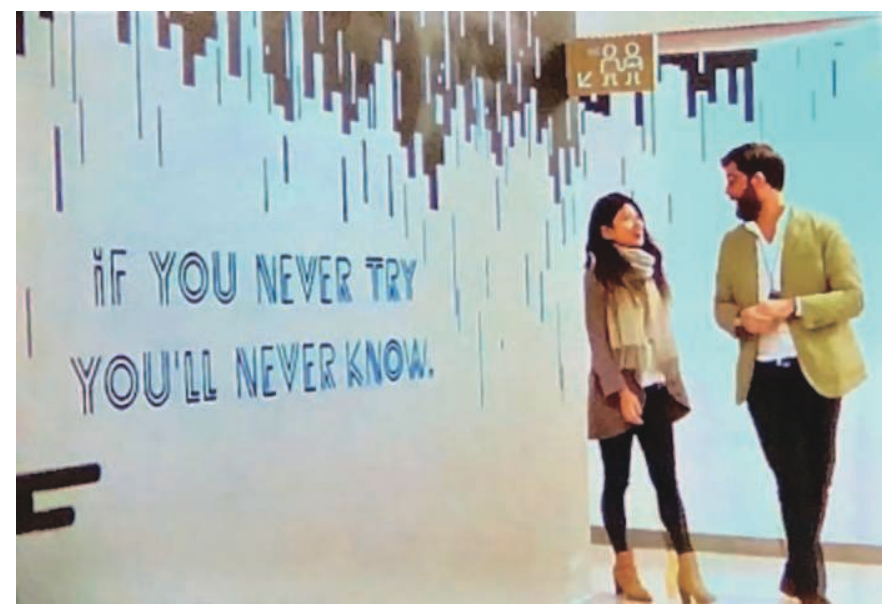

Figure 4. Picture of a muted video displayed on the Hub's screens that tells the story of a romantic encounter between two members in the restroom. Credit: photo courtesy of the author.

candidates wherever businesses are forced to adapt to a variety of codes across different markets and demand for cultural mediation consequently increases (Sassen 2010). For Hub members who dream of taking a share of the local market, the desirability of Chinese female professionals as intermediates who can help navigate the linguistic and practical obstacles of doing business in the region is bound up with the erotic appeal of Chinese female bodies. The women who find themselves as partners or employees of white entrepreneurs may find that these arrangements meet their sexual preferences and conform to their taste for working in a cosmopolitan environment, but they are less likely to embrace their assigned role as mediators: some complain that translation, booking hotels, and assisting visiting clients from abroad is not part of their job description. The view that their professional expertise is not properly recognised or valued exposes the relative lack of alignment between personal and business desires for those further down the hierarchy (Lordon 2014: 101-2). In promoting encounters between members, the Hub offers equal opportunity for white men and Chinese women to fulfil their racialised sexual desires but gives advantage to the former's fantasy of entering the Chinese market.

\section{Conclusion}

One day in May 2018, a member left his spot at the counter in the living room to give a tour to a new colleague. As he was leaving, he asked the man sitting next to him to keep an eye on his belongings. As if to suggest that this was a normal service to ask of a fellow member, he added: "Because we're a great community, right?" The audible sarcasm in his voice suggests that a closer analysis of speaking bodies could help disclose the gap between the members' perceptions and the Hub's discourse. On the basis of this visual ethnography, it is nevertheless clear that any voicing of disagreement is unlikely to materialise into practices that are visibly disruptive. As members commit to the Hub only insofar as they remain paying clients, those who do not adhere to its spirit can simply choose not to renew their membership. Those who continue to pay the subscription are therefore the ones satisfied with the experience of community sold by the Hub.

The community as commodity is produced through a visual management of bodies. In the virtual space, the Hub celebrates rather than conceals markers that distinguish different types of desirable bodies. Diversity is seen as adding value to the space on the condition that it does not challenge the visual homogeneity of the fashionable and fit bodies that reflect the members' active lifestyle. By contrast, the rural-urban migrant bodies needed to perform dirty work are entirely left out of virtual representations. Because they are indispensable in the physical space, their strange bodies are tolerated but masked and marked through the use of uniforms. An open space like the Hub, however, which needs to function as a platform connecting flows of information, money, and bodies, cannot be kept pure through spatial organisation alone. For this reason, it puts both members and employees to work as its eyes: members are asked to watch out for strangers, just as security guards are posted to monitor the space.

Rather than challenging the visual hierarchy of the space, the practices of the Hub's occupants further reinforce it. While members seek to increase their own visibility so as to earn recognition within an international professional community, cleaning ladies tend to hide from sight in order to avoid extra work. The divergence in how groups at different positions in the global division of labour inhabit the space comes from different meanings associated with the acts of looking and exposing oneself to the views of others. For undesirable migrants, work and play remains distinct as the new spirit of capitalism does not extend to them; to be seen is to be identified either as an abject being or as an object employed in the maintenance of the space, whereas to watch means to perform their job as monitors and caretakers. Conversely, for the desirable mobile professionals, to be seen and to look mean mutual recognition as working subjects who are also social beings in search of social connections that are both profitable and enjoyable.

Finally, the hierarchy of bodies in this globalised local community entails a differentiation between subjects with and without desires. While the Hub reduces unskilled workers to functional bodies, it recognises members as subjects who have professional interests, social needs, and sexual drives. As shown by the selective promotion of racial and gendered arrangements of bodies, these desires are nevertheless only acknowledged as long as they are likely to further capitalist accumulation. The coworking space is a site where the project of aligning individual passions and business interests reaches new levels of intensity. In early 2019, as the space was redesigned following the change of ownership, the Hub's slogan "Work hard, have fun" disappeared from the walls. Instead, a new motto appeared on mugs and the cleaning ladies' (still black) uniforms: "Do what you love."

I Aurélia M. Ishitsuka, PhD candidate, École des hautes études en sciences sociales, Université de Genève, Centre Maurice Halbwachs (ENS, EHESS, CNRS), 48 boulevard Jourdan 75014 Paris, France (aurelia-milika. ishitsuka@ehess.fr), https://orcid.org/0000-0002-5169-0748.

Manuscript received on $1^{\text {st }}$ August 2019. Accepted on 4 March 2020. 


\section{References}

AHMED, Sara. 2000. Strange Encounters: Embodied Others in PostColoniality. London and New York: Routledge.

BAUMAN, Zygmunt. 2001. Community: Seeking Safety in an Insecure World. Cambridge: Polity Press.

BOLTANSKI, Luc, and Ėve CHIAPELLO. [1999] 2011. Le Nouvel Esprit du Capitalisme (The New Spirit of Capitalism). Paris: Gallimard.

CASANOVA, Erynn Masi de. 2015. Buttoned up: Clothing, Conformity, and White-Collar Masculinity. Ithaca: Cornell University Press.

CHIAPELLO, Ève, and Norman FAIRCLOUGH. 2002. "Understanding the New Management Ideology: A Transdisciplinary Contribution from Critical Discourse Analysis and New Sociology of Capitalism." Discourse \& Society 13(2): 185-208.

CHEN, Xiangming (ed.). 2009. Shanghai Rising: State Power and Local Transformations in a Global Megacity. Minneapolis: University of Minnesota Press.

CONNELL, R.W., and Julian WOOD. 2005. "Globalization and Business Masculinities." Men and Masculinities 7(4): 347-64.

CONRADSON, David, and Alan LATHAM. 2005. "Transnational Urbanism: Attending to Everyday Practices and Mobilities." Journal of Ethnic and Migration Studies 31(2): 227-33.

DE GIORGI, Laura. 2017. "Alien Neighbours: Foreigners in Contemporary Shanghai." Journal of Architecture and Urbanism 41(2): 110-9.

DUNN, Kevin. 2010. "Embodied Transnationalism: Bodies in Transnational Spaces." Population, Space and Place 16(1): 1-9.

FARRER, James. 1999. "Disco 'Super-Culture': Consuming Foreign Sex in the Chinese Disco." Sexualities 2(2): 147-66.

FARRER, James. 2008. "From 'Passports' to 'Joint Ventures': Intermarriage between Chinese Nationals and Western Expatriates Residing in Shanghai." Asian Studies Review 32(1): 7-29.

FARRER, James. 2009. "Shanghai Bars - Patchwork Globalization and Flexible Cosmopolitanism in Reform-Era Urban-Leisure Spaces." Chinese Sociology \& Anthropology 42(2): 22-38.

GANDINI, Alessandro. 2015. "The Rise of Coworking Spaces: A Literature Review." Ephemera 15(1): 193-205.

GOFFMAN, Erving. 1956. The Presentation of Self in Everyday Life. Edinburgh: University of Edinburgh.

$\mathrm{GOH}$, Robbie B.H. 2014. "The Semiotics of Undesirable Bodies: Transnationalism, Race Culture, Abjection." Semiotica 200: 203-27.

GUAN, Jian, and Li LIU. 2014. "Recasting Stigma as a Dialogical Concept: A Case Study of Rural-to-Urban Migrants in China." Journal of Community \& Applied Social Psychology 24(2): 75-85.

HAN, Dong. 2010. "Policing and Racialization of Rural Migrant Workers in Chinese Cities." Ethnic and Racial Studies 33(4): 593-610.

HANSER, Amy. 2008. Service Encounters - Class, Gender, and the Market for Social Distinction in Urban China. Stanford: Stanford University Press.

HEARN, Alison. 2008. '"Meat, Mask, Burden': Probing the Contours of the Branded 'Self'." Journal of Consumer Culture 8(2): 197-217.

HIRD, Derek. 2009. "White-Collar Men and Masculinities in Contemporary Urban China." PhD dissertation, University of Westminster.

HOCHSCHILD, Arlie Russell. [1997] 2001. The Time Bind: When Home
Becomes Work and Work Becomes Home. New York: Henry Holt and Company.

HUCHES, Everett C. [1951] 1994. "Work and Self." In Lewis A. Coser (ed.), On Work, Race, and the Sociological Imagination. Chicago: University of Chicago Press. 57-66.

LONGHURST, Robyn. 2001. Bodies: Exploring Fluid Boundaries. London and New York: Routledge.

LORDON, Frédéric. 2014. Willing Slaves of Capital: Spinoza and Marx on Desire. London:Verso Books.

NIEKRENZ, Yvonne, Matthias D. WITTE, and Lisa ALBRECHT. 2016. "Transnational Lives. Transnational Bodies? An Introduction." Transnational Social Review 6(1-2): 93-5.

OSBURG, John. 2013. Anxious Wealth: Money and Morality among China's New Rich. Stanford: Stanford University Press.

OTIS, Eileen. 2011. Markets and Bodies - Women, Service Work, and the Making of Inequality in China. Stanford: Stanford University Press.

PEUTER, Greig de, Nicole S. COHEN, and Francesca SARACO. 2017. "The Ambivalence of Coworking: On the Politics of an Emerging Work Practice." European Journal of Cultural Studies 20(6): 687-706.

POW, Choon-Piew. 2007. "Securing the 'Civilised' Enclaves: Gated Communities and the Moral Geographies of Exclusion in (Post-)Socialist Shanghai." Urban Studies 44(8): 1539-58.

ROULLEAU-BERGER, Laurence, and Lu SHI. 2005. "Migrant Workers in Shanghai. Inequality, economic enclaves, and the various routes to employment." China Perspectives 58(March-April): 2-9.

SASSEN, Saskia. 2009. "The Global City Perspective: Theoretical Implications for Shanghai." In Xiangming Chen (ed.), Shanghai Rising: State Power and Local Transformations in a Global Megacity. Minneapolis University of Minnesota Press. 3-30.

SASSEN, Saskia. 2010. "Mondialisation et géographie globale du travail" (Globalisation and the global geography of labour). In Jules Falquet, Helena Hirata, Danièle Kergoat, Brahim Labari, Nicky Le Feuvre, and Fatou Sow (eds.), Le Sexe de la mondialisation. Genre, classe, race et nouvelle division du travail (The Sex of Globalisation. Gender, Class, Race and the New Division of Labour). Paris: Presses de Sciences Po. 27-41.

SPINUZZI, Clay. 2012. "Working Alone, Together: Coworking as Emergent Collaborative Activity." Journal of Business and Technical Communication 26(4): 399-441.

WANG, Bo, and Becky P.Y. LOO. 2017. "Hubs of Internet Entrepreneurs: The Emergence of Co-Working Offices in Shanghai, China." Journal of Urban Technology 24(3): 67-84.

WU, Weiyi. 2018. "Sharing or Integration: Rethinking the Localization of CoWorking Spaces in Shanghai." In Martin Lee and Nick Wilson (eds.), The Palgrave Handbook of Creativity at Work. Cham: Palgrave Macmillan. 223-43.

YU, Haiqing. 2017. "Editorial - Beyond E-Commerce. The Social Case of China's Digital Economy." China Perspectives 4(112): 3-8.

ZHANG, Li. 2001. "Contesting Crime, Order, and Migrant Spaces in Beijing." In Nancy N. Chen, Constance D. Clark, Suzanne Z. Gottschang, and Lyn Jeffery (eds.), China Urban: Ethnographies of Contemporary Culture. Durham: Duke University Press. 201-22.

ZHANG, Li. 2012. In Search of Paradise: Middle-Class Living in a Chinese Metropolis. Ithaca: Cornell University Press. 